\title{
RETROSPECTIVE ANALYTICAL STUDY OF ASSOCIATION BETWEEN ABO BLOOD GROUP AND MALIGNANCY
}

\author{
Siladri Sengupta ${ }^{1}$, Subhadip Sarkar ${ }^{2}$, Adnan Rehan Khan ${ }^{3}$
}

${ }^{1}$ Associate Professor, Department of Surgery, ESI-PGIMSR, ESIC Medical College, Joka.

${ }^{2}$ Assistant Professor, Department of Surgery, ESI-PGIMSR, ESIC Medical College, Joka.

3 Junior Resident, Department of Surgery, ESI-PGIMSR, ESIC Medical College, Joka.

\section{ABSTRACT}

\section{BACKGROUND}

The findings of Arid et al in 1953 regarding association between carcinoma of stomach and B blood group and successively in 1954 regarding association between peptic ulcer and 0 blood group opened a new approach to find association of blood group with other commonly occurring diseases. Blood type antigen system maybe apparently involved in the pathophysiology of wide range of human malignancy by interaction between glycan structures on red blood cells surface and different agents. Therefore, the present study aims to find out to examine the association between ABO blood group and different forms of malignancy, so that a preventive measure can be applied to the risk blood group population.

\section{MATERIALS AND METHODS}

Thirty (30) diagnosed malignant cases as study group and thirty (30) non-malignant cases as control group were selected amongst the surgical patients and ABO blood group were collected and registered. The ABO blood group and Rh factor of both the groups were determined using the tile or slide testing method and the frequency of occurrence of ABO and Rh blood group among malignant and non-malignant population was assessed. The frequency distribution of ABO blood group and Rh factor among the entire malignant population was compared with that of general non-malignant population by Chi-square test.

\section{RESULTS}

The present study indicates that the blood group (B) appears to have higher risk of developing malignancy compared to people of other blood groups, but it is insignificant as per Chi-square test.

\section{CONCLUSION}

The present study suggests that ABO blood group was found to be of non-potential risk factor in the development of malignancy.

\section{KEYWORDS}

Blood Group, Malignancy.

HOW TO CITE THIS ARTICLE: Sengupta S, Sarkar S, Khan AR. Retrospective analytical study of association between ABO blood group and malignancy. J. Evolution Med. Dent. Sci. 2017;6(55):4142-4145, DOI: 10.14260/Jemds/2017/897.

\section{BACKGROUND \\ The findings of Arid et al ${ }^{1}$ in 1953 regarding association between carcinoma of stomach and B blood group and then again in $1954^{2}$ regarding association between peptic ulcer and $\mathrm{O}$ blood group opened a new approach to find association of blood group with other commonly occurring diseases. The $\mathrm{ABH}$ histo-blood group antigens are a set of polymorphic and inherited glycoconjugate structures that are expressed on the \\ In the same way, blood type antigen system maybe apparently involved in the pathophysiology of wide range of human malignancy by interaction between glycan structures on red blood cell surface and different agents. Therefore, the present study aims to find out to examine the association between $\mathrm{ABO}$ blood group and different forms of malignancy, so that a preventive measure can be applied to the risk blood group population.} cell surfaces of human erythrocytes. ${ }^{3}$ The presence and lack of blood antigens in some blood groups induce blood membrane changes morphologically and functionally. The structure dependent functions of blood types can link the blood groups to health and diseases. ${ }^{4}$ It is now well established that the blood group exhibits some relation with some diseases like nasopharyngeal carcinoma, ${ }^{5}$ duodenal ulcer, ${ }^{6}$ epitaxis, ${ }^{7}$ anaemia ${ }^{8}$ and even cardiovascular diseases like coronary artery diseases and cardiac ischaemia.9,10

Financial or Other, Competing Interest: None.

Submission 26-01-2017, Peer Review 28-06-2017,

Acceptance 05-07-2017, Published 10-07-2017.

Corresponding Author:

Dr. Siladri Sengupta,

Flat-13CI, Bay Tower, Hiland Park,

1925 Chak Garia, P. O. Chak Garia,

Kolkata-700094, West Bengal.

E-mail: siladrisen2@gmail.com

DOI: $10.14260 /$ jemds $/ 2017 / 897$

\section{MATERIALS AND METHODS Selection of Subjects}

This descriptive comparative study was conducted in Surgical Unit II at ESIC Medical College, Joka, Diamond Harbour Road, Kolkata - 700104, between August 2015 to November 2016. This is the short study based on our observation with all malignant patients reported and hospitalised in our unit during the specified period are considered as study group, whereas the subjects for control group are selected from the non-malignant patients reported to our unit on the basis of simple random sampling as this sampling satisfies all the

\section{Study Design}

A total of 60 patients were included in the descriptive comparative study of which (30) patients were diagnosed with malignancy labelled as study group and (30) patients statistical analytic methods. 
were with benign disease without any malignancy labelled as control group. The study group was considered from the malignant patients reported to the said surgical unit II at ESIC Medical College, Joka, as the number of such patients reported to this unit were low during the period of study. The sample size in study group is concomitantly low and the sample size in control group was kept accordingly same as that of study group. The study was approved by the institutional ethical committee and has no conflict of interest.

\section{Determination of Blood Group}

With all aseptic precaution, the whole blood of suspected anaemic patients was collected in fasting condition by venepuncture using disposable syringes. The ABO blood group and $\mathrm{Rh}$ factor of both the groups were determined using the tile or slide testing method ${ }^{11}$ with the help of antisera-A, antisera-B and antisera-D and finally the frequency of occurrence of $\mathrm{ABO}$ and $\mathrm{Rh}$ blood group among diabetic and nondiabetic population was assessed.

\section{Statistical Analysis}

The frequency distribution of $\mathrm{ABO}$ blood group and Rh factor was expressed as percentage of each blood group and to establish the relationship between the blood group and malignancy. The frequency distribution (observed frequency) of blood group among the entire malignant population, i.e. study group $(\mathrm{N}=30)$ was compared with that of general non- malignant population, i.e. control group $(\mathrm{N}=30)$ and also with the reference frequency distribution of blood group among the general population by Chi-square test $\mathrm{t}^{12}$ and a $\mathrm{P}$ value of 0.05 was considered significant for all the statistical test conducted.

\section{RESULTS}

Out of the total 60 patients (30) were diagnosed with malignant conditions of different type. It is found that the prevalence of B blood group is highest followed by 0 , Group A and then Group AB in non-malignant population (Table 1). Statistical analysis by Chi-square test reflects that there is no significant difference between the observed frequency distribution and reference frequency distribution ${ }^{13}$ in West Bengal Zone. The Table 1 also shows that both the ABO blood group distribution and $\mathrm{Rh}$ distribution among the study group and control group is also insignificant $(\mathrm{P}<0.05)$. The apparent association between A blood group (33.33\% in malignant population against $16.67 \%$ in non-malignant population) and 0 blood group (10\% in malignant population against 33\% in non-malignant population) in control and expected (study) value is also not significant by Fisher's test (two-tailed test) using GraphPad software.12 The sex wise frequency distribution of both $\mathrm{ABO}$ group and Rh factors in study group also not significantly differs from control value or reference value as shown in Table No. 2 .

\begin{tabular}{|c|c|c|c|}
\hline $\begin{array}{c}\text { Blood } \\
\text { Group }\end{array}$ & $\begin{array}{c}\text { Observed Frequency Distribution of Study } \\
\text { Group, i.e. Malignant Group (N=30) }\end{array}$ & $\begin{array}{c}\text { Observed Frequency Distribution of } \\
\text { Control Group, i.e. Non-Malignant } \\
\text { Group (N=30) }\end{array}$ & $\begin{array}{c}\text { Frequency Distribution of } \\
\text { Reference Population }\end{array}$ \\
\hline $\mathrm{A}$ & $10(33.33 \%)$ & $5(16.67 \%)$ & $22 \%$ \\
\hline $\mathrm{B}$ & $13(43.33 \%)$ & $12(40 \%)$ & $38 \%$ \\
\hline $\mathrm{AB}$ & $4(4 \%)$ & $3(3 \%)$ & $8 \%$ \\
\hline 0 & $3(10 \%)$ & $10(33 \%)$ & $96 \%$ \\
\hline $\mathrm{Rh}+$ & $29(96.66 \%)$ & $28(93.33 \%)$ & $6 \%$ \\
\hline $\mathrm{Rh}-$ & $1(3.44 \%)$ & $2(6.67 \%)$ & \\
\hline \multicolumn{2}{|r|}{ Table 1. Blood Group Distribution between Study Group and Controls } \\
\hline
\end{tabular}

\begin{tabular}{|c|c|c|c|c|}
\hline Blood Group & \multicolumn{2}{|c|}{$\begin{array}{c}\text { Absolute Values in Study Group (Frequency } \\
\text { Distribution in \% Age) }\end{array}$} & $\begin{array}{c}\text { Absolute Values in Control Group (Frequency } \\
\text { Distribution in \% Age) }\end{array}$ \\
\hline & Male (N=10) & Female (20) & Male (N=17) & Female (N=13) \\
\hline A & $3(10)$ & $7(23.33)$ & $4(13.33)$ & $1(3.33)$ \\
\hline B & $4(13.33)$ & $9(30)$ & $6(20)$ & $2(20)$ \\
\hline AB & $1(3.33)$ & $3(10)$ & $1(3.33)$ & $4(13.67)$ \\
\hline O & $2(6.67)$ & $1(3.33)$ & $6(20)$ & $12(92.30)$ \\
\hline Rh+ & $10(100)$ & $19(95)$ & $16(94.11)$ & $1(7.70)$ \\
\hline Rh- & $0(0)$ & $1(5)$ & $1(5.89)$ & \\
\hline \multicolumn{7}{r}{} \\
\hline
\end{tabular}

\section{DISCUSSION}

The expression of blood group antigen alters during the process of cell differentiation and malignancy. Lack of A and B antigens resulted in promotion of cell motility, proliferation, invasion and metastatic tumour formation. ${ }^{14,15}$ Cancer is abnormal proliferation of different kinds of cells in the body and is categorised into three groups - carcinomas, sarcomas and leukaemia or lymphomas based on the primary types of cells where cancer cells originate. The most prevalent form of human cancer is carcinomas that are the malignancy of the epithelial cells. ${ }^{16}$ Most of the epithelial and endothelial cells can express $\mathrm{ABO}$ blood antigens, which are normally present on the red blood cells. ${ }^{17}$ ABO blood group antigens are carbohydrate structures relating to the cell surface glycolipids and glycoproteins, which are responsible for tumour development and progression. The expressions of blood group antigens are different in human normal tissue and carcinomas, while the type of differentiation of the 
epithelium determines $\mathrm{ABO}$ antigens, which are decreased in carcinoma as in oral carcinoma. Possible mechanism by which blood antigens relate to cancers includes hypermethylation of ABO gene promoter. ${ }^{18,19}$

Loss of Heterozygosity ( $\mathrm{LOH})$ at $\mathrm{ABO}$ locus and chromosome $9 q 43^{20}$ variant $\mathrm{ABO}$ alleles SNP (i.e. SNP correlated with $\mathrm{TNF})^{21-23}$ and presence of $\mathrm{H}$ blood group antigens on CD44 adhesion molecule. ${ }^{24}$ It was proved that ABO gene variability can effect glycosyltransferase expression and activity and result in cancer development. These mechanisms decrease the activity of glycosyltransferase and increase tumour progression, metastasis and migration. But, in the present study, no such role of $\mathrm{ABO}$ antigens or $\mathrm{Rh}$ antigens were found in the occurrence of malignancy. This study thus collaborates the fact that not always the blood group antigens has role in occurrence of some diseases, which is in accordance with the findings of some other researchers. ${ }^{25,26}$ However, for definite conclusion, multifaceted and multicentered retrospective study with large sample size is desirable.

\section{CONCLUSION}

The blood group is a genetic factor that has recognised association with multiple cancers. But, in this present study, no such correlation was found in between ABO blood group and malignancy. Though in this study, blood group (B) was found to be maximum amongst the study population in malignant cases followed by the group $(\mathrm{A}),(\mathrm{AB})$ and $(0)$, but it is insignificant in terms of frequency distribution of $\mathrm{ABO}$ blood group among non-malignant population. Chi-square test also failed to suggest any significant difference in between control and study group maybe because of very small sample size under each blood group. Hence, a multifaceted retrospective study with large sample size and multicentered study is desirable to come to an authentic conclusion.

\section{REFERENCES}

[1] Aird I, Bentall HH, Roberts JA. A relationship between cancer of stomach and the ABO blood groups. Br Med J 1953;1(4814):799-801.

[2] Aird I, Bentall HH, Mehigan JA, et al. The blood groups in relation to peptic ulceration and carcinoma of colon, rectum, breast, and bronchus; an association between the $\mathrm{ABO}$ groups and peptic ulceration. $\mathrm{Br}$ Med J 1954;2(4883):315-21.

[3] Sarafian V, Popov A, Taskov H. Expression of A, B and $\mathrm{H}$ blood-group antigens and carcinoembryonic antigen in human tumours. Zentralbl Pathol 1993;139(4-5):351-4.

[4] Iwamoto S, Withers DA, Handa K, et al. Deletion of Aantigen in a human cancer cell line is associated with reduced promoter activity of $\mathrm{CBF} / \mathrm{NF}-\mathrm{Y}$ binding region, and possibly with enhanced DNA methylation of a transferase promoter. Glycoconj J 1999;16(10):659-66.

[5] Seow LJ, Kwa SB, Teoh CK. A preliminary survey of ABO blood group frequency in nasopharyngeal carcinoma in Chinese patients. Sing Med J 1964;5(3):93-5.
[6] Clarke CA, Cowan WK, Edwards JW, et al. The relationship of $\mathrm{ABO}$ blood groups to duodenal and gastric ulceration. Br Med J 1955;2(4940):643-6.

[7] Adhikari P, Pramanik T, Pokharel R, et al. Relationship between blood group and epistaxis among Nepalese. Nep Med J 2008;10(4):264-5.

[8] Basak AK, Maji K. Blood group and anemia: exploring a new relationship. J Pub Health \& Epi 2013;5(1):43-5.

[9] Erikssen J, Thaulow E, Stormoken H, et al. ABO blood groups and coronary heart disease (CHD). A study in subjects with severe and latent CHD. Thromb Haemost 1980;43(2):137-40.

[10] Nydegger UE, Wuillemin WA, Julmy $F$, et al. Association of ABO histo-blood group $\mathrm{B}$ allele with myocardial infarction. Eur J Immunogenet 2003;30(3):201-6.

[11] Egesie UG, Egesie OJ, Usar I, et al. Distribution of abo, rhesus blood groups and haemoglobin electrophoresis among the undergraduate students of Niger Delta University, Nigeria. Nigerian J of Physiological Sciences 2008;23(1-2):5-8.

[12] http://Graphpad.com/quick cals/chisquare2/

[13] Basak AK, Tripathy SR, Majumder S. Frequency distribution of $\mathrm{ABO} \& \mathrm{Rh}$ blood group among the local domicile of East Midnapore, West Bengal. Ind J Pub Health Res Dev 2014;5(3):273-5.

[14] Dabelsteen E. ABO blood group antigens in oral mucosa. What is new? J Oral Pathol Med 2002;31(2):65-70.

[15] Ichikawa D, Handa K, Hakomori S. Histo-blood group A/B antigen deletion/reduction vs. continuous expression in human tumor cells as correlated with their malignancy. Int J Cancer 1998;76(2):284-9.

[16] Cooper GM. The development and causes of cancer. In: the cell: a molecular approach. $2^{\text {nd }}$ edn. Sinauer Associates: Sunderland, MA, USA, 2000.

[17] Dean L. The ABO blood group. In: Dean L. Blood groups and red cell antigens. Bethesda (MD): National centre for biotechnology information (US) 2005. Available from: http://www. ncbi.nlm.nih.gov/booksfNBK2267/

[18] Dabelsteen E, Gao S. ABO blood-group antigens in oral cancer. J Dent Res 2005;84(1):21-8.

[19] Chihara Y, Sugano K, Kobayashi A, et al. Loss of blood group $\mathrm{A}$ antigen expression in bladder cancer caused by allelic loss and/or methylation of the $\mathrm{ABO}$ gene. Lab Invest 2005;85(7):895-907.

[20] Gao S, Worm J, Guldberg P, et al. Genetic and epigenetic alterations of the blood group ABO gene in oral squamous cell carcinoma. Int $\mathrm{J}$ Cancer 2004;109(2):230-7.

[21] Wolpin BM, Kraft P, Xu M, et al. Variant ABO blood group alleles, secretor status, and risk of pancreatic cancer: results from the pancreatic cancer cohort consortium. Canccr Epidemiol Biomarkers prev 2010;19(12):3140-9.

[22] Rizzato C, Campa D, Pezzilli R, et al. ABO blood groups and pancreatic cancer risk and survival: results from the pancreatic disease Research (PAND0RA) consortium. Oncol Rep 2013;29(4):1637-44. 
[23] Lu X, Qian CN, Mu YG, et al. Serum CCL2 and serum TNF-a-two new biomarkers predict bone invasion, post-treatment distant metastasis and poor overall survival in nasopharyngeal carcinoma. Eur J Cancer 2011;47(3):339-46.

[24] Hallouin F, Goupille C, le Cabellec M, et al. Expression of $\mathrm{A}$ and $\mathrm{H}$ blood-group and of CD44 antigens during chemical rat colonic carcinogenesis. Glycoconj J 1997;14(7):801-8.
[25] Basak AK, Maji K. Study of relationship between ABO \& Rh blood group and type 2 diabetic mellitus. Intl J Med Res Rev 2016;4(11):1965-8.

[26] Kausik M, Kumar AB. The study of probable relationship between blood group \& hypertension. Intn J physiol 2015;3(2):44-7. 